E-ISSN : 2549-6581

Artikel Hasil Penelitian

Diterima : 1 Maret 2018

Direview : 5 Maret 2018

Dimuat : April - Juli 2018

\section{OPEN ACCESS}

Journal of Issues in Midwifer

\title{
Pengaruh Ekstrak Etanol Daun Turi Merah terhadap Jumlah Koloni Bakteri di Hepar dan Kadar TGF- $\beta$ Mencit Nifas yang Diinokulasi Staphylococcus aureus
}

\author{
Rahma Dian Hanifarizani $^{1 *}$, Sanarto Santoso ${ }^{2}$, I Wayan Agung Indrawan ${ }^{3}$ \\ ${ }^{1}$ Program Studi Sarjana Kebidanan Fakultas Kedokteran Universitas Brawijaya \\ ${ }^{2}$ Departemen Mikrobiologi Fakultas Kedokteran Universitas Brawijaya \\ ${ }^{3}$ Departemen Obstetri dan Ginekologi Rumah Sakit dr. Saiful Anwar Malang \\ Email: rahmadian anwar@ub.ac.id \\ Tlp : +6285334078900
}

\begin{abstract}
Postpartum is a period that is susceptible to infection that caused by bacteria through the birth canal injury. Strains of bacteria commonly found from isolation in puerperal infection is Staphylococcus aureus. Bacteria which enter through the vagina can spread through the lymphatic vessels or bloodstream and spread until the liver. The bacteria will produce toxin exotoxin triggering innate immunity. Furthermore, macrophages activated and released of proinflammatory cytokines. An exaggerated response of the release of proinflammatory cytokines can cause uncontrolled tissue damage. To compensate it, the body released antiinflammatory cytokines and TGF- $\beta$ that play in tissue repair. Treatment of infections commonly used antibiotics. However, some bacteria have become resistant, including Staphylococcus aureus. Developed various therapy adjuvant of natural materials, one is Sesbania Grandiflora L.pers that deemed to contain antibacterial. This study aims to prove the effect of leaf extract of red turi (Sesbania grandiflora L.Pers) to the number of bacterial colonies in the liver and the levels of TGF- $\beta$ in parturition mice inoculated by Staphylococcus aureus. This study used true experiment with posttest only control group design. Animals used were 25 postpartum mice were divided into 5 groups. Measurement of number of colonies use total plate count method while the levels of TGF- $\beta$ performed by ELISA. The result showed that extract of Sesbania Grandiflora L.pers can reduce the distribution of the average number of colonies of bacteria in the liver and increase the levels of TGF- $\beta$ in parturition mice inoculated by Staphylococcus aureus.

Hepar, Staphylococcus aureus, Sesbania grandiflora L.pers, TGF- $\beta$
\end{abstract}

Keywords: Hepar, Staphylococcus aureus, Sesbania grandiflora L.pers, TGF- $\beta$ 


\section{ABSTRAK}

Masa nifas merupakan periode yang rentan terhadap infeksi akibat masuknya bakteri melalui perlukaan jalan lahir. Strain bakteri yang umumnya ditemukan pada infeksi masa nifas adalah Staphylococcus aureus. Bakteri yang masuk melalui vagina dapat menyebar melaui pembuluh getah bening atau aliran darah dan menyebar ke deluruh tubuh termasuk ke hepar. Toksin eksotoksin baktri dalam tubuh memicu innate immunity. Makrofag aktif dan mengaktivasi pelepasan sitokin-sitokin proinflamasi. Respon berlebihan dari pelepasan sitokin-sitokin proinflamasi dapat menyebabkan kerusakan jaringan yang tidak terkontrol. Untuk mengimbangi hal tersebut, tubuh mengaktifkan sitokin-sitokin antiinflamasi dan TGF- $\beta$ yang berperan dalam perbaikan jaringan. Pengobatan terhadap infeksi umumnya menggunakan antibiotik. Namun beberapa bakteri telah menjadi resisten termasuk Staphylococcus aureus. Dikembangkan berbagai terapi adjuvant dari bahan alam, salah satunya Sesbania Grandiflora L.pers yang dianggap memiliki kandungan antibakteri.Tujuan penelitian ini untuk membuktikan pengaruh ekstrak daun turi merah (Sesbania grandiflora L.Pers) terhadap jumlah koloni bakteri di hepar dan kadar TGF- $\beta$ pada mencit nifas yang diinokulasi Staphylococcus aureus.Penelitian ini menggunakan true experiment dengan posttest only control group design. Hewan coba yang digunakan adalah 25 ekor mencit nifas yang dibagi menjadi 5 kelompok. Pengukuran jumlah koloni memakai metode total plate count sedangkan kadar TGF- $\beta$ dilakukan dengan metode ELISA. Hasilnya adalah pemberian ekstrak daun turi merah mampu menurunkan sebaran rerata jumlah koloni bakteri di hepar dan meningkatkan kadar TGF- $\beta$ pada mencit nifas yang diinokulasi Staphylococcus aureus.

Kata kunci: Hepar, Staphylococcus aureus,Sesbania grandiflora L.pers, TGF- $\beta$

1Korespondensi: Rahma Dian Hanifarizani. Surel: rahmadian_anwar@ub.ac.id 


\section{PENDAHULUAN}

Di negara-negara berkembang angka kematian ibu (AKI) pada masa nifas memiliki rata-rata lebih tinggi dibandingkan pada masa antenatal maupun intranatal ${ }^{1}$. Penyebab kematian ibu masa nifas yang paling sering adalah perdarahan $(28 \%)$ dan infeksi $(11 \%)^{2}$. Pada saat masa nifas akan terdapat perlukaan-perlukaan pada jalan lahir yang memicu masuknya bakteri patogen. Bakteri dapat masuk dan menyebar ke berbagai jaringan tubuh. Salah satu bakteri yang umum diisolasi pada kasus infeksi nifas adalah Staphylococcus aureus. Infeksi oleh Staphylococcus aureus ditandai dengan kerusakan jaringan yang menyebabkan aktivasi respon kekebalan tubuh. Staphylococcus aureus yang masuk ke dalam tubuh menghasilkan toksin berupa eksotoksin akan direspon oleh innate immunity ${ }^{3}$. Bakteri ini akan dipresentasikan oleh makrofag selaku sel penyaji (Antigen Presenting Cell / $A P C$ ). Ikatan makrofag dan bakteri memicu pelepasan sitokin proinflamasi seperti TNF- $\alpha$, IL-1, IL-6 dan IL-8. Peningkatan konsentrasi TNF- $\alpha$ memiliki hubungan dengan syok sepsis dan kematian. Respon proinflamatori yang berlebihan dapat menyebabkan kerusakan jaringan yang tidak terkontrol. Untuk mengimbangi pengeluaran sitokin proinflamasi berlebihan, tubuh mengaktifkan sitokin-sitokin antiinflamasi seperti IL-4, IL-10 dan sitokin respon perbaikan kerusakan yang disebabkan oleh peradangan dengan menghasilkan Transforming Growth Factor Beta (TGF- $\beta$ ). Peran TGF- $\beta$ adalah mempromosikan perbaikan jaringan dengan cara menghambat sitokin proinflamasi yang disekresi oleh makrofag 4 . Pengobatan terhadap infeksi Staphylococcus aureus biasanya menggunakan berbagai jenis antibiotik. Hasil pengobatan seringkali tidak memuaskan karena ketidakteraturan pemakaian. Akibatnya, bakteri Staphylococcus aureus menjadi resisten terhadap antibiotik seperti penisilin G, ampisilin, sulbenisilin, amoksisilin, dan meticilin ${ }^{5}$. Staphylococcus aureus yang resisten memiliki kemampuan memproduksi $\beta$ laktamase, suatu enzim yang menghidrolisis ikatan cincin $\beta$ laktam pada antibiotik. Peran $\beta$ laktam dalam antibiotik adalah mencegah pembentukan dinding sel bakteri yang berupa peptidoglikan sehingga bakteri lisis lalu mati. Resistensi bakteri terhadap antibiotik juga dapat terjadi karena adanya plasmid yang mengkodekan gen bakteri sehingga kebal terhadap antibiotik ${ }^{6}$.

Meluasnya resistensi bakteri ini terhadap antibiotik, memacu berbagai langkah pengobatan alternatif dengan pemberian bahan alam $^{7}$. Salah satu tanaman yang digunakan adalah turi merah (Sesbania grandiflora). Daun turi merah yang telah diteliti memiliki kandungan saponin, flavonoid, dan tanin memiliki efek antibakteri ${ }^{8}$. Kandungan etanol pada daun turi merah juga memiliki fungsi sebagai immunomodulator $^{9}$.

Penelitian mengenai turi merah (Sesbania grandiflora) sebagai antibakteri telah banyak dilakukan. Namun yang dikaitkan dengan infeksi nifas belum banyak dibahas. Oleh karena itu, penelitian ini bertujuan membuktikan adakah pengaruh pemberian ekstrak 
Staphylococcus aureus terhadap Jumlah Koloni Bakteri di Hepar dan Kadar TGF- $\beta$ Mencit Nifas yang Diinokulasi Staphylococcus aureus.

\section{METODE PENELITIAN}

Desain penelitian ini menggunakan eksperimental sesungguhnya (true experimental design) dengan pendekatan postest only control grup design

\section{Subjek Penelitian}

Sampel dalam penelitian ini adalah 25 ekor mencit (Mus musculus) nifas yang dibagi menjadi 5 kelompok yaitu kelompok kontrol negatif, kelompok kontrol positif (inokulasi Staphylococcus aureus), kelompok P1 (inokulasi Staphylococcus aureus dan diberi ekstrak daun turi merah dosis 125 $\mathrm{mg} / \mathrm{kgBB}$ ), $\quad$ P2 (inokulasi Staphylococcus aureus dan diberi ekstrak daun turi merah dosis $250 \mathrm{mg} / \mathrm{kgBB}$ ), serta (inokulasi Staphylococcus aureus dan diberi ekstrak daun turi merah dosis $500 \mathrm{mg} / \mathrm{kgBB}$ ). Penggunaan hewan coba telah memenuhi persyaratan etik dari komisi etik Fakultas Kedokteran Universitas Brawijaya.

\section{Pembuatan Mencit Model Infeksi Nifas \\ Pembuatan mencit model
infeksi dilakukan dengan cara inokulasi bakteri Staphylococcus aureus $5 \times 10^{7} \mathrm{CFU}$ sebanyak $0,2 \mathrm{ml}$ pada setiap mencit secara intravaginal ${ }^{10}$.}

\section{Proses Ekstraksi Daun Turi Merah \\ Ekstraksi daun turi merah dilakukan di UPT Materia Medica Batu dengan metode maserasi}

dengan pelarut etanol 96\%. Hasil ekstraksi berbentuk pasta dan disimpan pada suhu $4^{\circ} \mathrm{C}$ sebelum digunakan.

\section{Dosis Pemberian Ekstrak Daun Turi Merah}

Ekstrak daun turi merah diberikan 2 jam setelah inokulasi bakteri. Bahan berbentuk pasta diencerkan terlebih dulu dengan aqudest. Dosis yang diberikan dibagi menjadi 3 yaitu 125 $\mathrm{mg} / \mathrm{kgBB}, \quad 250 \mathrm{mg} / \mathrm{kgBB}$, dan $500 \mathrm{mg} / \mathrm{kgBB}$ ). Pemberian ekstrak dilakukan melaui oral sebanyak $1 \mathrm{ml}$ pada setiap mencit menggunakan sonde.

\section{Penghitungan Jumlah Koloni Bakteri Staphylococcus aureus di Hepar}

Penghitungan jumlah koloni bakteri di hepar dilakukan dengan metode uji total plate count (hitungan cawan). Sampel dari organ hepar yang digerus dan diambil sebanyak $1 \mathrm{ml}$ ke dalam media cawan petri steril, kemudian Mannitol Salt Agar (MSA) dituang di atas permukaan media. Sampel kemudian ditunggu hingga membeku lalu diinkubasi 2x24 jam. Setelah masa inkubasi, jumlah koloni yang tumbuh dalam media dihitung menggunakan colony counter (alat penghitung koloni bakteri). Untuk menghindari kontaminasi, tindakan dilakukan dalam laminary flow.

\section{Pengukuran Kadar TGF- $\beta$}

Pengukuran kadar TGF- $\beta$ dari sampel darah dilakukan dengan metode Enzymed-Linked Immunosrbent Assay (ELISA). Kit ELISA menggunakan Anti-mouse TGF- $\beta$ Bioassay Technology 
Laboratory nomor katalog E0285Mo.

\section{Teknik Analisis Data}

Semua data yang diperoleh dianalisis menggunakan software SPSS 23. Data TGF- $\beta$ yang terdistribusi normal pada kelompok kontrol negatif dan positif dengan dianalisis dengan t-test. Sedangkan data pada kelompok perlakuan dianalisis dengan One Way ANOVA. Data jumlah koloni bakteri dianalisis melalui rerata jumlah Staphylococcus aureus dari hasil kultur pada MS.A

\section{HASIL PENELITIAN}

\section{Pengaruh}

Pemberian

EkstrakDaun Turi Merah pada Jumlah Koloni Bakteri di Hepar

Hasil kultur koloni bakteri pada media MSA tidak ditemukan koloni bakteri pada kelompok kontrol negatif dan P3 (inokulasi bakteri dan pemberian ekstrak daun turi merah $500 \mathrm{kmg} / \mathrm{kgBB}$ ). Sedangkan koloni bakteri Staphylococcus aureus pada organ hepar ditemukan pada kelompok kontrol positif, P1 dan P2.

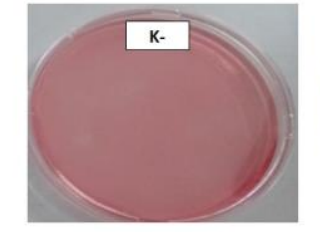

P1
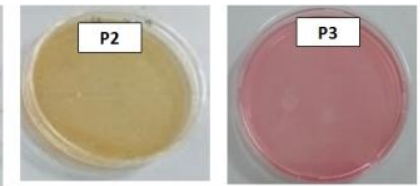

Gambar 1 Kultur Koloni Staphylococcus aureus di Hepar mencit pada MSA

Keterangan: Pada media manitol salt agar (MSA), bakteri Staphylococcus aureus menunjukkan pertumbuhan koloni berwarna kuning keemasan dikelilingi zona berwarna kuning karena memfermentasi manitol. Tampak zona berwarna merah muda pada kelompok kontrol negatif dan P3. Sedangkan tampak zona kuning pada kelompok kelompok kontrol positif, P1, dan P2.

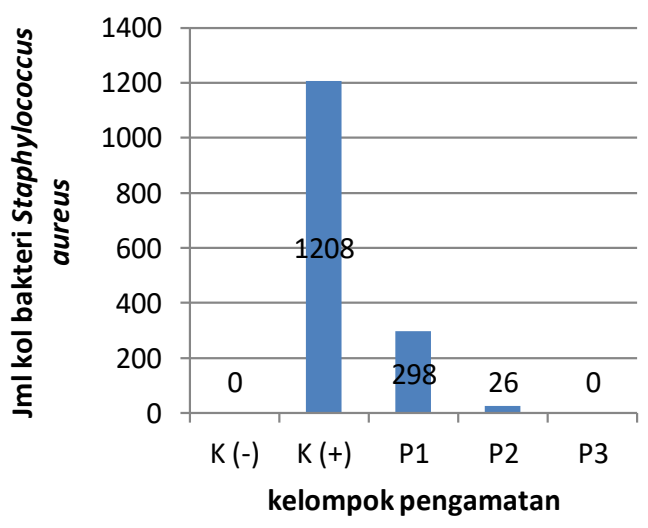

\section{Gambar 2 Histogram Sebaran Rerata Jumlah Koloni Bakteri di Hepar}

Keterangan: terjadi peningkatan jumlah koloni bakteri pada kelompok positif dibandingkan dengan kelompok kontrol negatif. Kelompok kontrol positif memiliki jumlah koloni bakteri paling banyak. Pada kelompok P1 tampak penurunan jumlah koloni bakteri di hepar dibandingkan dengan kelompok kotrol positif. Pada kelompok P2, jumlah sebaran rerata bakteri juga mengalami penurunan dibandingkan dengan kelompok P1. Dan pada kelompok P3 tidak tampak adanya koloni bakteri Staphylococcus aureus pada organ hepar seperti pada kelompok kontrol negatif.

\section{Pengaruh Pemberian Ekstrak Daun Turi Merah terhadap Kadar TGF- $\beta$}




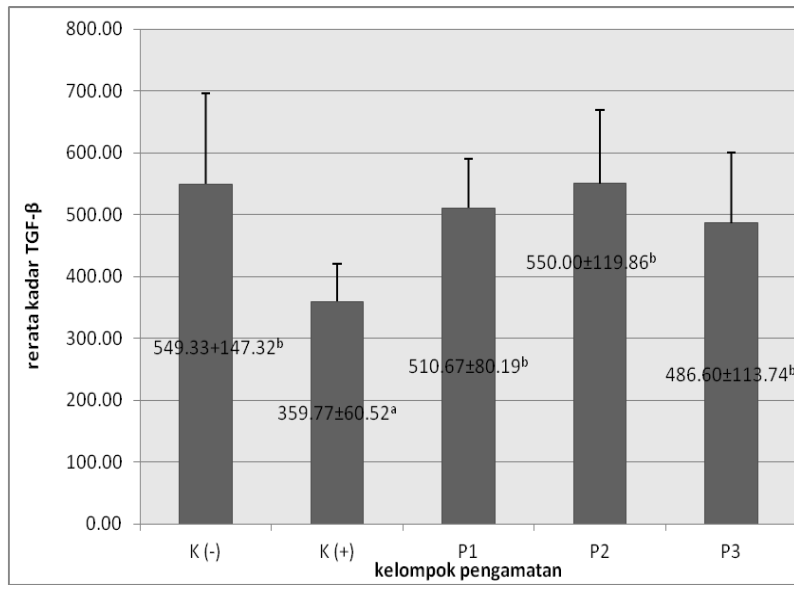

bakteri jika dibandingkan dengan kelompok kontrol positif. Nilai sebaran rerata jumlah koloni pada kelompok P3 bahkan menunjukkan rerata $\pm S d \quad 0 \pm 0$. Nilai ini sama dengan sebaran rerata pada mencit kelompok kontrol negatiatau mencit sehatf .

Pemberian esktrak daun turi merah menurut hasil penelitian ini mampu menurunkan jumlah koloni bakteri Staphylococcus

\section{Gambar 3 Histogram Rerata Kadar TGF- $\beta$}

Keterangan: Gambar 3 menunjukkan histogram rerata kadar TGF- $\beta$ pada kontrol negatif (mencit sehat), kontrol positif (mencit inokulasi Staphylococcus aureus), dan 3 kelompok mencit inokulasi Staphylococcus aureus dan pemberian ekstrak daun turi merah dengan dosis $125 \mathrm{mg} / \mathrm{kgBB}, \quad 250 \mathrm{mg} / \mathrm{kgBB}$, dan $500 \mathrm{mg} / \mathrm{kgBB}$. Tampak ada peningkatan rerata kadar TGF- $\beta$ dari dosis $125 \mathrm{mg} / \mathrm{kgBB}$ $\mathrm{ke}$ dosis $250 \mathrm{mg} / \mathrm{kgBB}$. Sedangkan terjadi penurunan kadar TGF- $\beta$ dari dosis $250 \mathrm{mg} / \mathrm{kgBB}$ jika dibandingkan dengan pemberian ekstrak daun turi merah dosis $500 \mathrm{mg} / \mathrm{kgBB}$. Namun, rerata kadar TGF- $\beta$ pada dosis ketiga $\left(486.60 \pm 113.74^{\mathrm{b}} \mathrm{pg} / \mathrm{mL}\right)$ masih lebih tinggi dibandingkan dengan rerata kadar TGF- $\beta$ pada kelompok mencit yang diinokulasi bakteri Staphylococcus aureus $\left(359.77 \pm 60.52^{\mathrm{a}} \mathrm{pg} / \mathrm{mL}\right)$. Adapun nilai rerata kadar TGF- $\beta$ pada kelompok perlakuan pemberian ekstrak daun turi merah dosis $125 \mathrm{mg} / \mathrm{kgBB}, 250 \mathrm{ml} / \mathrm{kgBB}$, dan $500 \mathrm{mg} / \mathrm{kgBB}$ secara statistik tidak berbeda secara signifikan dengan nilai rerata kadar TGF- $\beta$ pada kelompok kontrol negatif atau mencit sehat. Dengan kata lain ekstrak Sesbania grandiflora L.pers mampu meningkatkan kadar TGF- $\beta$ secara bermakna pada mencit yang diinokulasi bakteri Staphylococcus aureus.

\section{PEMBAHASAN}

\section{Pengaruh Pemberian Ekstrak Daun Turi Merah pada Jumlah Koloni Bakteri di Hepar}

Pada semua kelompok pemberian ekstrak daun turi merah terdapat penurunan jumah koloni aureus. Hal ini diduga karena kandungan bahan kimia yang terdapat dalam ekstrak daun turi merah yaitu flavonoid, saponin, dan tanin. Bahan-bahan kimia ini mempunyai efek antibakteri. Flavonoid memiliki mekanisme kerja sebagai antibakteri dengan cara mencegah sintesis asam nukleat, menghambat fungsi membran sitoplasma dan mencegah terjadinya metabolisme energi melalui gangguan pada respirasi seluler ${ }^{11}$. Saponin menurunkan tegangan permukaan sehingga mempengaruhi permeabilitas sel. Jika permeabilitas sel rusak, komponen penting dalam tubuh bakteri akan keluar sehingga bakteri akan mati. Tanin memiliki kemampuan merusak dinding sel bakteri sehingga dapat menghilangkan permeabilitas membran sel. Hasil penelitian lain menyebutkan bahwa tanin memiliki kemampuan menginaktivasi kemampuan perlekatan bakteri pada sel Host ${ }^{12}$.

Selain itu, adanya bakteri yang masuk ke dalam hepar akan mengaktivasi makrofag dalam hepar yang disebut sel Kupferr. Sel ini bertugas sebagai filter terhadap bahan-bahan asing termasuk bakteri patogen. Mekanisme pembersihan terhadap masuknya 
benda asing disebut dengan clearance. Salah satu mekanisme clearance adalah dengan cara mengaktivasi peningkatan IgG di hepar $^{13}$.

\section{Pengaruh Pemberian Ekstrak Daun Turi Merah terhadap Kadar TGF- $\beta$}

Berdasarkan gambar 3, rerata kadar TGF- $\beta$ plasma pada kelompok kontrol positif adalah $359.77 \pm 60.52 \mathrm{pg} / \mathrm{mL}$ sedangkan kelompok perlakuan pemberian ekstrak daun turi merah dengan dosis $125 \mathrm{mg} / \mathrm{kgBB}$ adalah $510.67 \pm 80.19 \mathrm{pg} / \mathrm{mL}$, dengan dosis $250 \mathrm{mg} / \mathrm{kgBB}$ adalah $550.00 \pm 119.86 \mathrm{pg} / \mathrm{mL}$, dan dengan dosis $\quad 500 \mathrm{mg} / \mathrm{kg}$ BB adalah $486.60 \pm 113.74 \mathrm{pg} / \mathrm{ml}$. Terdapat perbedaan yang bermakna $(p=0.000)$. Berdasarkan nilai reratanya, kadar TGF- $\beta$ plasma pada kelompok kontrol positif lebih kecil nilainya dibandingkan rerata kadar TGF- $\beta$ plasma pada kelompok perlakuan pemberian ekstrak daun turi merah. Ini berarti bahwa mencit model infeksi nifas memiliki nilai rerata kadar TGF- $\beta$ plasma lebih rendah dibandingkan dengan mencit model infeksi nifas yang mendapat ekstrak daun turi merah.

Pada kelompok P1 (dosis ektrak turi merah $125 \mathrm{mg} / \mathrm{kgBB}$ ), kadar TGF- $\beta$ lebih tinggi dibandingkan dengan kelompok kontrol positif. Terdapat perbedaan yang bermakna antara kelompok kontrol positif dengan kelompok P1. Sedangkan kadar TGF- $\beta$ pada kelompok P2 (dosis ektrak turi merah $250 \mathrm{mg} / \mathrm{kgBB}$ ) lebih tinggi daripada kelompok perlakuan 1 . Namun menurut uji statistik, tidak ada perbedaan yang bermakna antara kelompok P1 dengan P2. Artinya, pemberian ekstrak daun turi merah pada dosis $125 \mathrm{mg} / \mathrm{kgBB}$ dan $250 \mathrm{mg} / \mathrm{kgBB}$ memiliki kemampuan yang sama dalam meningkatkan kadar TGF- $\beta$ dalam darah mencit.

Pada kelompok P3 (dosis ektrak turi merah $500 \mathrm{mg} / \mathrm{kgBB}$ ), kadar TGF- $\beta$ lebih tinggi daripada kelompok kontrol positif, akan tetapi lebih rendah daripada kelompok perlakuan 1 dan kelompok perlakuan 2. Menurut uji beda statistik, ada perbedaan bermakna antara kelompok kontrol positif dengan kelompok P3. Tetapi tidak ada perbedaan yang bermakna antara kadar TGF- $\beta$ pada kelompok P1 maupun P2 dengan P3. Penurunan kadar TGF- $\beta$ pada pemberian ekstrak dosis $500 \mathrm{mg} / \mathrm{kgBB}$ diduga karena fungsi efek antibakteri telah bekerja secara maksimal. Dapat dikatakan bahwa dalam penelitian ini dosis ekstrak daun turi merah berbagai dosis (125mg/kgBB, 250 mg/kgBB, dan $500 \mathrm{mg} / \mathrm{kgBB}$ ) memiliki kemampuan yang sama dalam meningkatkan kadar TGF- $\beta$ pada mencit yang diinokulasi Staphylococcus aureus.

Peningkatan kadar TGF- $\beta$ dapat terjadi karena berakhirnya proses inflamasi. TGF- $\beta$ adalah sebagai pengatur perbaikan jaringan setelah reaksi imunologis dan inflamasi mereda ${ }^{4}$. Aktivasi TGF- $\beta$ meningkat apabila sitokin proinflamasi mengalami penurunan. Peneliti menduga adanya peningkatan kadar TGF- $\beta$ dapat terjadi karena sitokin proinflamasi telah menurun sehingga peradangan segera berkahir.

TGF- $\beta$ juga dianggap
memiliki peran sebagai
immunosupressan. Aktivasi TGF- $\beta$
mampu menghambat produksi IL-2


dan IFN- $\gamma^{14}$. Melalui penghambatan ini, maka TGF- $\beta$ berfungsi dalam mengontrol respon imun dan peradangan. TGF- $\beta$ sebagai pengontrol sistem immun adalah dengan mengaktivasi sel Treg. Sel Treg akan meregulasi aktivasi dari sel Th1 dan Th2 sehingga aktivitasnya menjadi seimbang. Th1 berperan mengaktivasi IFN-y dan IL-2 yang meningkatkan aktivasi makrofag untuk fagositosis sedangkan Th2 menginduksi aktivasi IL-4 dan IL-10 yang berfungsi menghambat sintesis IFN$\mathrm{Y}$ sehingga peradangan tidak terus terjadi ${ }^{4}$.

Kecepatan berakhirnya inflamasi diduga akibat pengaruh kandungan dari ekstrak daun turi merah yaitu flavonoid, saponin, dan tanin. Flavonoid dianggap mampu meningkatkan kerja immunostimultan sel-sel radang termasuk makrofag sehingga aktivasi makrofag dalam mengeliminasi bakteri menjadi lebih cepat $^{16}$. Berkurangnya jumlah bakteri akan mempercepat berakhirnya proses inflamasi. Saponin mampu meningkatkan proliferasi sel dan menginduksi sel $T$ dan sel $B$. Aktivasi sel $B$ akan menginduksi aktivasi antibodi $\lg \mathrm{G}$, IgA dan $\lg \mathrm{M}$. Tanin dalam ekstrak daun turi merah diduga mencegah peningkatan sitokin proinflamasi yang berlebihan dengan menghambat faktor transkripsi NfkB.Tingginya kadar TGF- $\beta$ dapat pula terjadi karena sifatnya sebagai promotor matriks ekstraseluler. Aktivasi TGF- $\beta$ secara langsung menginduksi ekspresi kolagen dan fibronektin yang berfungsi sebagai faktor pertumbuhan jaringan. Pada proses penyembuhan luka, TGF- $\beta$ berperan penting dalam deposisi matriks ekstraseluler. Peneliti menduga tingginya kadar TGF- $\beta$ digunakan sebagai perbaikan jaringan yang rusak akibat proses melahirkan ${ }^{15}$.

Hasil penelitian ini menunjukkan

bahwa ekstrak daun turi merah

dapat berpengaruh dalam

meningkatkan kadar TGF- $\beta$.

\section{SIMPULAN}

Pemberian ekstrak daun turi merah (Sesbania grandiflora L. Pers) terbukti dapat menurunkan jumlah koloni bakteri di hepar dan dapat meningkatkan kadar TGF- $\beta$ pada mencit nifas yang diinokulasi Staphylococcus aureus.

\section{DAFTAR PUSTAKA}

1. Ahmed, Salma; Kawaguchiya, Mitsuyo. Drug Resistance and Molecular Epidemiology of Aerobic Bacteria Isolated from Puerpural Infection in Bangladesh, 2015; 21 number 3.

2. Kementerian Kesehatan RI. 2013. Pusat Data dan Informasi Kementerian Kesehatan RI Mother's day. www.depkes.go.id.

3. Nahid, A., Agdas, S., Farhad, H., 2009. Bacteria Isolated from Postpartum Infections. Health Journal, Journal of Family and Reproductive No. 2 June 2009.

4. Abbas, A. K., Lichmant, A. H. 2015. Cytokines. In: Cellular and Molecular Immunology. $5^{\text {th }}$. Ed. Philadelpia: W. B. Saunders Company.

5. Jawetz, Melnick, and Adelberg. 2005. Mikrobiologi Kedokteran. Salemba Medika. Jakarta.

6. Naim, R. 2004. Atlas Tanaman Obat Indonesia Jilid II. Jakarta:Trubus. 
7. Nasution Ns, dkk.,2010. Keunggulan Turi sebagai pakan Ternak. Palembang: Ditjen Peternakan dan Keswan BPTU Sembawa.

8. Nuria, M. C., Faizatun A., \& Sumantri. 2009. Uji Aktivitas Antibakteri Ekstrak Etanol Daun Jarak Pagar (Jatropha Curcas L) Terhadap Bakteri Staphylococcus aureus ATCC 25923, Escherichia coli ATCC 25922, dan Salmonella typhi ATCC 1408. Jurnal IImu ilmu Pertanian, 5 (2): 26-37

9. Lazarenko L., Babenko L., Sichel L.S., Pidgorskyi V., Mokrozub V., Voronkova O., et al., 2012. Antagonistic action of lactobacilli and bifidobacteria in relation to Staphylococcus aureus and their influence on the immune response in cases of intravaginal staphylococcosis in mice, Probiotics and antimicrobial proteins, 4(2): 78-89

10. Cuishnie, T. P., Lamb, A. J. Antimicrobial Activity of Flavonoids. International Journal of Antimicrobial Agents, 2005; 26 : 343-356.

11.Skogh, Blomhoff, Eskild, Berg. 1985 Hepatic uptake of Circulating IgG Immune Complexes. Sweden: University of Linkoping

12. Baratawidjaja, K. G. dan Rengganis, I. 2014. Imunologi Dasar Edisi ke-10. Jakarta: Fakultas Kedokteran Universitas Indonesia.

13. Stout, R, D and Suttles, J. 1997. $T$ Cell Signaling of Macrophage Function in Inflammatory Disease. Frontiers in Bioscience, 2, d197-206.

14. Baratawidjaja, K. G. dan Rengganis, I. 2014. Imunologi Dasar Edisi ke-10. Jakarta:
Fakultas Kedokteran Universitas Indonesia.

15. Verrecchia F. Dan Mauviel A. Transforming growth factor-beta and fibrosi. World Gastroenterol. 2007: 13: 3056-62 